\title{
TURAS AL SIYASIY PARTAI POLITIK ISLAM DI INDONESIA
}

\author{
Achmad Yasin \\ Fakultas Syariah IAIN Sunan Ampel Surabaya
}

\begin{abstract}
Abstrak: Turas al siyasiy merupakan sesuatu yang hadir dan menyertai di masa kekinian kita dalam pola tindakan di ruang empiris kehidupan kita, yang berasal dari masa lalu (yang benar-benar terjadi dalam kurun sejarah perpolitikan bangsa Indonesia) berupa ideologi, pemikiran politik, fatsun politik, etika politik, birokrasi dan peradaban politik bangsa kita, apakah itu dari masa lalu kita, atau masa lalu orang lain, ataukah masa lalu tersebut di masa lalu yang jauh maupun yang dekat berupa tipologi politik, afiliasi politik, konstelasi politik, tradisi politik aliran partai politik Islam dalam kancah perpolitikan Indonesia.Tradisi politik aliran dari partai-partai Islam dalam usaha menformulasikan ideologi Islam dalam tradisi pertarungan di dalam khazanah intelektual dan dalam ruang lingkup kebudayaan dan perilaku politik umat Islam sejak zaman revolosi kemerdekaan hingga periode reformasi, dimana tradisi dan perilaku politik aliran berideologi Islam mengalami degradasi dalam perolehan suara yang sangat besar dibandingkan dengan perolehan suara partai yang berideologi kebangsaan dan pluralisme. Dalam konteks ini, Partai Islam dalam mainstream tradisi menformalisasikan ajaran dan doktrin Islam sebagai dasar negara dan memperjuangkan berdirinya negara Islam, ternyata tidak mendapatkan respon dari umat Islam. Sehingga pada tataran akhir, partai Islam beradaptasi menjadi partai politik yang berasaskan dan menerima Pancasila dan berdemensi partai kebangsaan dan tetap menjadikan Islam sebagai gerakan kultral, dimana Islam sebagai basis perjuangan dalam mewujudkan nilai-nilai etika politik (Islam) dan bukan sebagai Islam politik untuk menghadapi perkembangan realitas umat Islam dan tututan agar wajah Islam yang bersifat akomodatif dengan relasi negara.
\end{abstract}

Kata Kunci: Turas al siyasiy, tradisi politik, aliran idiologis, akomodatif, etika politik 


\section{Pendahuluan}

Setelah berdirinya Budi Utomo, lahir pula organisasi Islam, antara lain; Serikat Islam, Muhammadiyah, NU, yang orientasi berdirinya dalam bidang: politik kebangsaan, kerakyatan, syiar keagamaan, dakwah maupun sosial. Organisasi Islam yang pertama muncul dalam masyarakat Indonesia adalah Serikat Islam - yang pada permulaan bernama Serikat Dagang Islam - yang didirikan oleh H. Samanhudi pada tahun 1911 di Solo. Orientasi organisasi ini pada awalnya pada bidang ekonomi, yakni bertujuan untuk menyaingi kegiatan ekonomi penjajah Belanda dan golongan Cina. Organeasasi ini berdasarkan asas Islam, serta bercita-cita untuk memajukan kehidupan ekonomi masyarakat. Serikat Islam berkembang dengan pesat dan pada tahun 1912 di bawah pimpinan H.O.S. Cokroaminoto, serta mulai nampak haluan organisasinya pada bidang politik. ${ }^{1}$

Fokus perjuangan dan pergerakan organisasi massa dan politik di Indonesia yang bermotivasi untuk bersatu dan berjuang melawan penjajah melalui jalan damai/kooperatif. Pergerakanpergerakan tersebut punya pengaruh dalam mencerdaskan masyarakat serta menanamkan kesadaran kebangsaan, dan punya andil dalam menumbuhkan semangat nasionalisme dan kesadaran berpolitikdan kebangsaan. Perkembangan pergerakan tersebut sebagian berubah haluan menjadi partai politik untuk melawan kedudukan penjajah baik Belanda maupun Jepang, walaupun mendapat larangan dari pihak penjajah mereka tetap berjuang. Dari perjalanan tersebut menunjukkan bahwa partai politik di Indonesia lahir dalam merintis Kebangkitan Nasional.

Perjalanan partai politik pasca jaman Belanda mendapat larangan yang keras dari penjajah Jepang dengan mengeluarkan Dekrit yang menyatakan bahwa melarang setiap diskusi, rapat

'M.Rusli Karim, Perjalanan Partai Politik di Indonesia: Sebuah Potret Pasang Surut (Jakarta:R.Grafindo Persada, 1993), h. 19. 
politik atau organisasi yang berhubungan dengan massa rakyat dan politik negeri ini. ${ }^{2}$

Dalam kedaan itu partai politik Islam memutuskan untuk memfungsikan organisasi federasi dari partai-partai politik Islam: MIAI (Majelis Islam A'la Indonesia) - yang dibentuk sebelum penjajah Jepang datang - yang berhaluan politik Islam, tapi dengan pengawasan dan di bawah naungan pemerintah Jepang. ${ }^{3}$ Misi dan tugas yang dilaksanakan antara lain adalah menjamin posisi dan tempat yang layak bagi Islam di dalam masyarakat Indonesia dan mengharmoniskan Islam Indonesia dengan tuntutan perubahan zaman. Akan tapi pada tahun 1943, MIAI dibubarkan oleh pemerintah Jepang. Dengan pembubaran organisasi tersebut para tokoh Islam tidak menyerah, mereka mendirikan organisasi Masyumi (Majelis Syuro Muslimin Indonesia) yang langsung mendapatkan status badan hukum dari pemerintahan Jepang, karena orientasi dan programnya bersifat moderat dan kooperatif dengan Jepang, melalui strategi ini, pengurus teras Masyumi di bawah komando KH.Hasyim Asy`ari dalam mengantisipasi tindakan Pemerintah Jepang yang bersifat represif, seperti yang telah dialami oleh MIAI, dan pada titik kulminasinya perjuangan Masyumi tidak berhenti sampai mencapai kemerdekaan bagi Indonesia.

Setelah Indonesia merdeka, pemerintah Indonesia membuka kran politik bagi masyarakat berupa pemberian kebebasan untuk mendirikan partai politik, kebijaksanaan itu atas dasar usulan Badan Pekerja Komite Nasional Indonesia Pusat (BP- KNIP) - yang saat itu berfungsi sebagai parlemen sementara - kepada pemerintah untuk memberi kesempatan kepada partai politik, dengan tujuan agar partai politik memperkuat, memperjuangkan dan mempertahankan kemerdekaan serta menjamin keamanan masyarakat Indonesia. Oleh sebab itu, pemerintah mengeluarkan Maklumat Nomor X yang ditandatangani oleh Wakil Presiden

\footnotetext{
${ }^{2}$ Hari J. Benda, Bulan Sabit dan Matahari Terbit,(Jakarta: Dunia Pustaka Jaya, 1990), h. 142

3 Ibid, h. $144-177$.
}

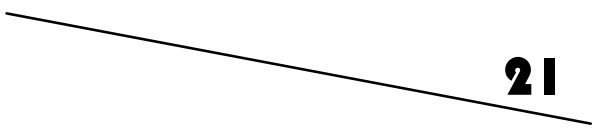


Mohammad Hatta, yang dengan tegas memutuskan bahwa pemerintah ingin partai politik dapat menyalurkan aliran/faham dalam masyarakat Indonesia, dan partai politik itu harus terbentuk dan tersusun sebelum pemilihan anggota Badan Perwakilan Rakyat pada bulan Januari $1946 .{ }^{4}$

Keputusan pemerintah dalam Maklumat Nomor $X$ itu mendapat sambutan dari masyarakat, sehingga muncul partaipartai politik yang berbeda-beda haluan dan aliran untuk mengikuti pemilihan umum. Partai politik Islam yang mengikuti pada waktu itu adalah Masyumi, Partai Serikat Islam Indonesia (PSII), Partai Tarbiyah Islamiyah ( Perti ). Masyumi didirikan berdasarkan Muktamar Islam Indonesia di Yogyakarta pada 7-8 November $1945^{5}$, yang diikuti oleh tokoh-tokoh Islam seperti tokoh dari organisasi Nahdlatul ‘Ulama' dan Muhammadiyah, dan memutuskan memakai nama Masyumi yang berbeda nama pada waktu penjajahan Jepang.

Masyumi mendapatkan suara dan pengikut yang termasuk banyak, karena organisasi yang dipelopori oleh Nahdlatul 'Ulama', Muhammadiyah, Perikatan Umat Islam, dan Persatuan Islam serta diikuti oleh organisasi dari berbagai daerah. Akan tetapi, pada tahun 1952 Nahdlatul 'Ulama' (NU) memisahkan dari Masyumi dan berdiri sendiri sebagai partai politik dan kemudian dikuti oleh Muhammadiyah. Pada masa pemerintahan Orde Lama peranan partai politik Islam cukup berpengaruh pada parlemen, seperti pada saat Perdana Menteri dipegang oleh M. Natsir sebagai wakil dari Masyumi.

Kemajuan partai politik Islam tercermin dari perolehan suara pada pemilu 1955, yakni dari akumulasi partai politik yang mengikuti pemilu - Masyumi, NU, PSII, Perti, PPTI, dan AKUI -

\footnotetext{
${ }^{4}$ M. Rusli Karim, Perjalanan Partai ..., h. 269 ; dan Abdul Qadir Jaelani, Peta Sejarah Perjuangan Politik Umat Islam, (Surabaya: CV.Tri Bakti, 1996), h.98

${ }^{5}$ Deliar Noer, Partai Islam di Pentas Nasional 1945-1956, (Jakarta:Pustaka Utama Grafiti, 1987), h. 47
} 
mengalami kemajuan dari $24 \%$ menjadi $45,2 \%$, sehingga banyak kursi yang diperoleh dalam DPRS.

Akan tetapi, kebijaksanaan pemerintah Orde Lama dengan memakai sistem Demokrasi Terpimpin, regim Orla membubarkan partai-partai yang tidak sehaluan dengan Presiden Soekarno. Hal itu diputuskan karena keadaan dalam parlemen tidak stabil yang disebabkan adanya perbedaan ideologi partai politik. Sehingga keluar keputusan yang mengakui keberadaan partai politik PNI, NU, PKI, Partai Katolik, Partai Indonesia, Partai Murba, PSII (kecuali PSII Abikusno) dan IPKI, ${ }^{6}$ sehingga Presiden Soekarno secara langsung pada tahun 1960 membubarkan Partai Masyumi.

Runtuhnya rezim Orde Lama dan munculnya Rezim Orde Baru partai politik yang mengikuti pemilihan umum pertama tahun 1971 sebanyak 10 partai, yakni Golkar, NU, Parmusi, PNI, PSII, Parkindo, Partai Katolik, Partai Murba, Perti, dan Ikatan Pendukung Kemerdekaan Indonesia (IPKI). Penyelenggaraan pemilu pertama pada 3 Juli 1971 tersebut menunjukkan hasil akhir bahwa perolehan suara dimenangkan oleh Golkar dengan memperoleh 227 kursi (34. 348.673 suara) atau 62,8\%, adapun partai Islam seperti NU menduduki peringkat kedua dan diikuti oleh Parmusi. ${ }^{7}$ Menjelang pemilu berikutnya, Orde Baru menghapuskan harapan yang sempat terlintas dalam benak pimpinan parpol Islam, yang telah mencapai posisi tiga besar pada pemilu pertama, Orba menetapkan suatu kebijaksanaan pemerintah yang menerapkan politik deparpolisasi yakni dengan mengadakan penyederhanaan sistem kepartaian. Dengan adanya sistem yang baru, maka memaksa kepada empat partai Islam untuk berfusi yakni; Parmusi, NU, Perti, dan PSII, menyatu dalam satu wadah Partai Persatuan Pembangunan ( PPP ), sedangkan wadah lain tempat bergabung yakni Partai Demokrasi Indonesia ( PDI ) yang berasalkan dari partai PNI, Partai Katolik, Parkindo, IPKI, dan Murba.

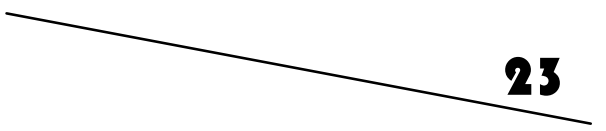


Sekilas bersatunya partai-partai Islam dalam PPP akan menguntungan karena akan muncul satu suara, tetapi sistem tersebut -menurut Syamsuddin Haris - justru menjadi simbol berakhirnya sejarah panjang partai-partai politik Islam; karena sistem fusi itu merupakan rekayasa pemerintah Orde Baru. ${ }^{8}$ Akhirnya partai hasil fusi tersebut mengalami perpecahan internal yang tak kunjung selesai sehingga rangking yang diperoleh dalam Pemilihan Umum tidak pernah menduduki peringkat pertama melainkan suaranya seakan terkooptasi oleh kelompok yang lebih berkuasa.

Hal itu disertai dengan sering terjadi aspirasi politik umat Islam yang terhenti di tengah jalan, sehingga peranan dan pergerakan umat Islam tergeser dari kegiatan politik menuju pada pergerakan kultural. ${ }^{9}$ Namun ketika Presiden Soeharto turun dari jabatannya, hal ini menjadi titik awal runtuhnya rezim orde baru, dan memasuki era baru yang diawali dengan memberikan perubahan seperti mengadakan Pemilu pada tahun 1999 dan memberikan kebebasan terhadap pers. Dengan perubahan dalam bidang politik yakni memberikan kebebasan terhadap partai politik untuk berdiri, guna mengikuti Pemilu dengan beberapa persyaratan. Maka muncul beberapa partai politik yang mendaftarkan diri untuk mengikuti Pemilihan Umum pada tahun 1999 dengan latar belakang masing-masing, baik berdasar kepentingan bangsa atau kelompok, masa lalu atau pun yang lainnya, asalkan dapat memenuhi persyaratan yang ditetapkan KPU. Sehingga partai politik Islam yang mengikuti cukup banyak, seperti PPP,PBB,PNU, Partai Kebangkitan Bangsa ( PKB ), Partai Keadilan ( PK ), dan lainnya.

Dalam percaturan politik pasca Orde Baru partai politik Islam muncul dengan landasan bahwa ketika penekanan-

\footnotetext{
${ }^{8}$ Abdul Aziz Thaba, Islam dan Negara Dalam Politik Orde Baru (Jakarta:Gema Insani Press, 1996), h. 235

9 M.Syafii Anwar, Pemikiran dan Aksi Islam Indonesia Sebuah Kajian Politik Tentang Cendekiawan Muslim Orde Baru (Jakarta: Paramadina, 1995), h. I29- 139
} 
penekanan menjadi dominan dan kebebasan sipil dan politik dikebiri,maka concern agama terhadap ketidakadilan dan pembelaan terhadap kebenaran secara gradual akan membesar dan lebih eksplisit seiring dengan besarnya tingkat ketidakadilan tersebut. Dua masalah tersebut menjadi dasar utama bangkitnya sense politik umat Islam Era Reformasi yang menjadi serangan balik terhadap rekayasa dominasi politik Orde Baru yang berkepanjangan. Tersumbatnya aspirasi umat Islam dan banyaknya ketidakadilan baik yang formal maupun struktural, dan hilangnya moral politik serta termarginalnya kaum lemah menjadi alasan munculnya respon politik umat Islam.

Gelombang perjalanan partai politik Islam pernah terjadi dalam sejarah politik Indonesia telah menjadi bukti pertarungan tiga ideologi besar dalam pentas politik Indonesia pra-1965, yaitu ideologi Nasionalis-sekuler, Komunis, dan Islam. ${ }^{10}$ Akibat dari peristiwa tersebut pentas politik di Indonesia tidak berlangsung dengan harmonis melainkan penuh dengan konflik dan perbedaan yang mendasar.Banyaknya konflik internal dalam partai politik Islam, maka banyak pemikiran muncul untuk menyumbangkan pemikiran, dari cendekiawan Muslim antara lain Nurcholish Madjid yang mengeluarkan slogan yang berbunyi; "Islam, Yes, Partai, No!". Slogan tersebut muncul menanggapi atas sikap partaipartai politik Islam yang menjadi wadah ide-ide Islam politik yang hendak diperjuangkan berdasarkan mainstream Islam, sedangkan ide-ide dan pemikiran Islam itu menjadi sumber phobia, memfosil dan kehilangan dinamika. ${ }^{11}$ Selain itu, partai politik Islam tidak berhasil membangun image positif dan simpatik melainkan memunculkan image sebaliknya yakni sebagian umat Islam yang duduk dalam kekuasaan birokrasi dan teknokrat negara reputasinya semakin menanjak dalam bidang korupsi dan KKN. Sehingga menurutnya partai politik Islam seharusnya tidak menawarkan ideologinya melainkan menawarkan hal-hal yang

\footnotetext{
${ }^{10}$ Kuntowijoyo, Identitas Politik Umat Islam (Bandung:Mizan, 1997), h. 20

" Nurcholish Madjid, Islam Kemodernan dan Keindonesiaan (Bandung:Mizan, 1999), h. 204-205
}

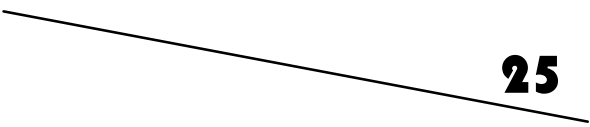


dibutuhkan oleh masyarakat, atau dengan kata lain masyarakat sekarang tidak membutuhkan ideologi, dan janji-janji yang tidak ada buktinya. Pendapat itu berdasarkan catatan sejarah dan telah menjadi tradisi perpolitikan Islam bahwa pada masa sebelumnya partai politik banyak menawarkan ideologi dan framework yang tidak dapat membantu memperbaiki kehidupan masyarakat Indonesia dalam aspek pembelaan spiritual dan psikologis serta bantuan material atau dengan memberikan sesuatu yang dibutuhkan oleh masyarakat, sehingga masyarakat arus bawah tetap menunjukkan kesetiaan pada setiap Pemilu.

Dari perjalanan partai politik Islam di Indonesia terdapat banyak masalah yang mucul, tapi yang paling mendasar adalah masalah keberadaan atau posisi ideologi dan tujuan partai politik Islam tersebut. Masalah keberadaan partai politik Islam di Indonesia ini apakah berpengaruh terhadap perilaku berpolitik di Indonesia. Permasalahan ideologi partai politik Islam banyak yang menggunakan ideologi Islam sampai pada ideologi Islam ingin dimasukkan sebagai ideologi negara Indonesia. Sedangkan tujuan partai politik Islam terdapat pada tujuan mendirikan negara Islam; apakah tujuan ini tepat sebagai alasan demi kemajuan kehidupan masyarakat Indonesia?.

\section{Konseptual Turas Al Siyasiy}

Bahwa makna kata turas (bahasa Arab- yang bermakna tradisi) dalam tulisan ini diartikan dari konsep pemikiran seorang filosof muslim modern dari Maroko, Muhammad Abed al Jabiri yakni kata turas dalam bahasa Arab berasal dari kata warasa yang secara gramatikal searti dengan kata irs, wirs, dan miras yang berbentuk masdar( verbal noun ) yang diartikan dengan: " segala yang diwarisi" ( yang ditinggalkan) oleh manusia; baik berupa harta, kekayaan, kehormatan, maupun status sosial, dan keningratan. Dan 
menurut al Jabiri kata turas dan derivasinya bersumber dari al Qur'an $S$. al Fajr: 19, S. Ali Imran: 18, dan S. al Hadid: $10^{12}$.

Maka dari konseptual Abed al Jabiri tersebut, penulis memperluas definisi di atas untuk turas al siyasiy ( tradisi politik) adalah: "sesuatu yang hadir dan menyertai masa kekinian kita, yang berasal dari masa lalu ( yang benar-benar terjadi dalam kurun sejarah perpolitikan bangsa Indonesia ) berupa ideologi, pemikiran, fatsun politik, etika politik dan peradaban politik, apakah itu dari masa lalu kita, atau masa lalu orang lain, ataukah masa lalu tersebut di masa lalu yang jauh maupun yang dekat"13. Dengan demikian makna turas al siyasiy dalam ruang lingkup yang umum merupakan transmisi pemaknaan atas nilai-nilai peninggalan sejarah ( periodisasi dan perjalanan politik ) masyarakat dan bangsa dan bersumber dari: (1) tradisi non material yang berupa hasil-hasil pemikiran dan budaya bangsa, (2) tradisi yang bersifat material, seperti nilai estetika dan rancang bangun dari arsitektural bangunan, monumen, prasasti yang berpengaruh hingga saat ini dalam politik, (3) tradisi kebudayaan nasional, yakni segala hasil kreasi yang bersifat empiris maupun teknikal yang kita miliki dari masa lalu kita, dan (4) tradisi kemanusiaan yang universal, yaitu nilai-nilai kehidupan sosial kemasyarakatan dan etika yang mempengaruhi jalan hidup kita sebagai bangsa. Misalanya, wawasan kebangsaan, idiologi bangsa, budaya gotong royong, perilaku kekeluargaan yang bebasis keadilan sosial, ideologi politik, perjuangan politik/kultur politik suatu komunitas .dan lainnya. ${ }^{14}$

Partai politik Islam di Indonesia, dapat diuraikan bahwa makna partai yang merupakan dari bahasa Latin yakni "partire" yang bermakna membagi kekuasaan, sedangkan menurut istilah :segolongan orang atau perkumpulan yang seasas, sehaluan,

\footnotetext{
${ }^{12}$ Muhammad Abed al Jabiri, Post Tradisionalisme Islam, terj.Ahmad Baso (Jogyakarta: LkiS ), h.6.

13 Ibid, h. 20.

${ }^{14} \mathrm{Ibid}$, h.25.
}

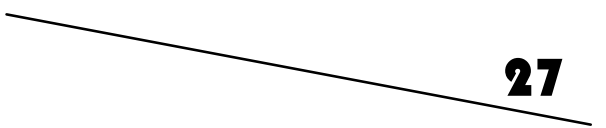


setujuan dalam sesuatu bidang ( hal ketatanegaraan ). ${ }^{15}$ Dengan demikian, konteks partai politik Islam adalah segolongan orangorang yang berkumpul / berorganisasi dengan satu asas, haluan, cita-cita, dan tujuan untuk berkuasa yang bersifat ideologi Islam dalam memperjuangkan kepentingan politiknya dan membangun realitas politik berdasarkan syariah yang besumber dari ajaran al Qur'an dan al Hadis, Sedangkan yang dimaksudkan partai politik Islam di Indonesia dalam tulisan ini, adalah partai politik Islam yang ikut dalam pentas politik di Indonesia sebagai kontestan peserta pemilu.

\section{Tradisi Partai Politik Islam}

Partai-partai yang berbasis politik aliran, atau idiologis agama merupakan partai-partai yang menempatkan asas perjuangannya pada agama, baik dalam aliran politik Islam, kristen, atau doktrin agama lainnya. Kekuatan umat Islam dalam perpolitikan Indonesia dalam kamuflase, the silent majority yang tidak pernah diteliti dengan akurat, mengapakah umat Islam yang mayoritas tidak pernah mendukung partai Islam menuju kemenangan politis dalam pertarungan pemilu yang demokratis di Indonesia?. Dalam Zaman demokrasi liberal banyak partai Islam ,misalnya Masyumi, PSII, Perti, Partai NU tidak pernah eksis dalam konstelasi politik nasional Indonesia, pada hal secara mayoritas dominan? Hal ini terlihat dalam era reformasi partai yang berbasis dan beridiologi aliran agama, terutama berasaskan Islam, diantaranya PPP, PK, PBB, PNU, Masyumi Baru, dan PSII 1905 mengalami degradasi yang sangat tajam dan legislator dari politikus yang partai politiknya berazas Islam dan muslim idiologis hanya dalam peringkat ketiga. ${ }^{16}$

15 Bambang Cipto, Partai Politik (Jogyakarta:Pustaka Pelajar, 1996), h.I; dan W.J.S.Poerwadarminta, Kamus Umum Bahasa Indonesia (Jakarta:Balai Pustaka, 1993), h. 7 I2.

${ }^{16}$.Al.Chaidar, Pemili 1999 Pertarungan Idiologis Partai-partai Islam Versus Partai Sekuler (Jakarta:Darul Falah,200 I),h.246-8

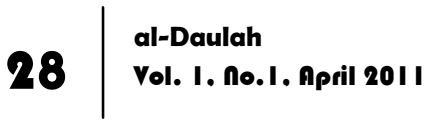


Pemikiran tentang partai Islam di Indonesia dimulai dari pemikiran tentang pergerakan polikus muslim dalam BPUPKI dan panitia sembilan yang ditunjuk oleh PPKI dalam menyusun dan mempersiapkan dasar negara Indonesia yang diproklamasikan pada 17 Agustus 1945 dan dilanjutkan dalam perdebatan yang sangat sengit di Majelis Konstituante hasil pemilu 1955 yang sangat demokratis pertama kali di Indonesia dan dimana posisi polikus Islam diperlukan dalam kehidupan politik Islam dalam menyuarakan aspirasi ummat Islam di Indonesia. Dari pemikiran pergerakan tersebut berkembang menjadi pemikiran politik Islam dan diantaranya membahas tentang Partai Politik Islam. Pemikiran tentang partai politik Islam meliputi beberapa poin;

Pertama,Posisi dan Keberadaan Partai Politik Islam. Keberadaannya pada masa penjajahan dan orde lama itu tidak dapat terelakkan, akan tetapi pada masa orde baru dan era reformasi eksistensi partai Islam lebih heterogen simbolisasinya dari pada visionernya partai Islam.Bahwa partai politik tidak perlu menamakan sebagai partai politik Islam. Bahkan dalam merespon partai yang menamakan dirinya partai Islam adalah partai politik tidak perlu memakai labelisasi kata Islam, karena walaupun tidak memakai label (tambahan) Islam partai tersebut dapat tumbuh menjadi besar asalkan benar-benar memeperjuangkan kepentingan rakyat secara keseluruhan. ${ }^{17}$ Hal ini adalah tanggapan terhadap partai yang menamakan sebagai partai Islam pada Era-Reformasi ini, seperti PPP dan lain-lain.

Pendapat itu cerminan dari pemikiran yang muncul pada tahun 1970-an melalui ungkapkan berupa slogan yang berbunyi "Islam, Yes, Partai Islam, No!" yang disebabkan pada waktu itu partai-partai Islam sebagai wadah ide-ide yang hendak berjuang berdasarkan Islam, tapi ide-ide atau pemikiran tersebut sedang mengalami kehilangan dinamika sehingga partai Islam tidak dapat membangun image yang positif dan simpatik masyarakat pada

${ }^{17}$ Nurcholish Madjid, Dialog Keterbukaan (Jakarta:Paramadina, 1998), h. 184

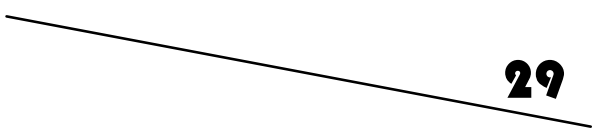


umumnya. Pendapat tersebut merupakan gerakan pembaharuan yang dilakukannya untuk membebaskan jiwa muslim Indonesia. Dengan kata lain bahwa gerakan itu untuk memajukan atau membangkitkan umat Islam dengan cara menghilangkan kecacatan yang telah melekat pada diri mereka, yakni melepaskan nilai tradisional dan beralih untuk mencari nilai-nilai yang berorientasi ke masa depan. ${ }^{18}$ Langkah tersebut dianggap perlu, karena masyarakat atau umat Islam tidak lagi dapat membedakan nilai-nilai transendental dan yang bersifat temporal sehingga Islam senilai dengan tradisi, dan menjadi islamis yang sederajad dengan tradisi.

Gerakan itu juga menganjurkan adanya kebebasan berfikir untuk memperhatikan tuntutan-tuntutan pada kondisi-kondisi masyarakat, sebab pemikiran yang yang masih tebal dengan diliputi oleh stagnasi dan apriori, dan pemikiran yang tidak dapat membedakan yang duniawi dan ukhrawi adalah akibat dari tiadanya kebebasan berfikir, sehingga tidak dapat menyelesaikan masalah. Agar dapat menyelesaikan masalah dalam masyarakat pemikiran Islam harus disesuaian, dipergeser, diperbaharui, dan dikoordinasikan agar membuat ide-ide yang sejalan dengan zaman sekarang ini. ${ }^{19}$ Untuk dapat membedakan hal yang Duniawi dan Ukhrawi maka slogan tersebut sebenarnya bermaksud mengadakan proses sekularisasi yakni proses penduniawian dengan memberikan perhatian yang lebih besar dari pada kehidupan Duniawi yang mencakup sikap objektif dalam hukum dan mengadakan penyimpulan-penyimpulan yang jujur. ${ }^{20}$ Proses itu untuk membedakan hal yang Duniawi dan yang Ukhrawi atau dengan kata lain bahwa pengakuan wewenang Ilmu Pengetahuan dan penerapannya dalam membina kehidupan duniawi, dan ilmu terus berproses dan berkembang menuju kesempurnaan, sehingga proses itu merupakan proses dinamis.

\footnotetext{
${ }^{18}$ Nurcholish Madjid, Islam Kemodernan dan Keindonesiaan, h. 206

19 Ibid, h. 209.

20 lbid, h. 218
} 
Pada masa lalu terlihat atau muncul adanya Politik Aliran dalam pentas politik Nasional, menurut Nurcholish Madjid bahwa Politik Aliran pasti ada, sehingga bila ingin menghapuskan itu hanya omong kosong belaka. ${ }^{21}$ Dan sekarang Politik aliran tidak berlaku lagi pada saat ini, sehingga istilah santri dan abangan tidak relevan lagi, karena sekarang para santri sudah menyebar kemana-mana, sehingga sepatutnya partai Islam bersikap lebih terbuka.

Sesuai dengan gerakan pembaharuan, pada saat sekarang dibutuhkan organisasi yang berimplikasikan non-tradisionalisme dan non-sektarianisme. Peranan Partai Islam seharusnya menjadi kelompok penekan, pressur gruop agar orang Islam lebih efektif menjadi kontrol atas setiap kebijakan yang berimplikasikan langsung terhadap kehidupan rakyat kecil yang powerless di bidang akses politik dan ekonomi .

Kedua, ideologi Partai Politik Islam. Berbicara tentang partai politik Islam tentu tidak lepas dari adanya Ideologi Islam yang pernah muncul pada masa dulu baik dalam diri partai maupun cita-cita dalam negara, dan adanya ingin memberlakukan Piagam Jakarta pada akhir-akhir ini karena adanya kekecewaan akan banyaknya penyelewengan atau pelanggaran atas hukum-hukum yang berlaku dan menganggap bahwa Pancasila tidak cocok lagi untuk masa sekarang. Dalam masalah ideologi partai Islam di Indonesi dapat diformasikan dalam bahwa Islam bukanlah sebuah Ideologi, meskipun ia bisa malah seharusnya berfungsi sebagai sumber-sumber ideologi bagi pemeluknya. Tapi Islam sendiri terbebas dari keterbatasan-keterbatasan sebuah ideologi yang sangat memperhatikan konteks ruang dan waktu itu. Pandangan kepada Islam sebagai ideologi bisa berakibat merendahkan agama itu menjadi sederajat dengan berbagai ideologi yang ada. ${ }^{22}$

${ }^{21}$ Nurcholish Madjid, Dialog Keterbukaan.... h. 185-/86

${ }^{22}$ Nurcholish Madjid, Cita-Cita Politik Islam Era Reformasi (Jakarta:Paramadina, 1999), h. 47

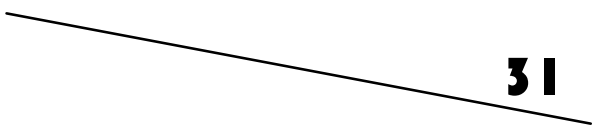


Adapun aspirasi ideologis itu cenderung kepada kekuatan, tidak kritis dan bersifat tertutup padahal sifat tertutup itu berbahaya. ${ }^{23}$ Karena itu beliau berpendapat tentang posisi agama bahwa seharusnya agama sebagai sumber inspirasi moral dan etika, sehingga bukan seperti Idiomatik tempo dulu. ${ }^{24}$ Dengan demikian beliau tidak sependapat bila Islam dijadikan sebuah ideologi karena berakibat akan merendahkan agama Islam dan menjadikan Islam menjadi tidak bersifat terbuka. Akan tetapi muncul pertanyaan ideologi apa yang digunakan oleh Muslim ?, maka jawabannya tak lain adalah sebagai Muslim tidak dibenarkan memilih suatu ideologi yang bertentangan dengan jiwa Islam, seperti sistem mendukung kezaliman. Sebagaimana pendapat beliau bahwa keabsahan ideologi diperoleh hanya jika penganutnya mampu membuktikan ia mendapat dukungan prinsip-prinsip ajaran agamanya. ${ }^{25}$ Sehingga memakai ideologi bagi orang Islam tidaklah diharuskan ideologi yang ini atau itu, melainkan harus memakai ideologi yang dibenarkan dan tidak bertentangan dengan ajaran-ajaran Islam itu sendiri.

Partai moderen yang baik adalah memakai Ideologi Demokrasi sebagai ideologi, karena pertimbangan prinsipil, sebab nilai-nilai demokrasi dibenarkan dan didukung oleh semangat ajaran-ajaran Islam dan fungsinya juga sebagai aturan permainan politik yang terbuka. Aturan itu diperlukan guna mewujudkan sistem politik secara holistik dan baku suatu mekanisme untuk mengadakan koreksi atas kesalahan-kesalahan pelaksanaan pemerintahan dan penggunaan kekuatan ditinjau dari sudut kepentingan rakyat dan ketentuan-ketentuan konstitusional sewaktu-waktu. ${ }^{26}$

Adapun tentang Pancasila, UUD, dan Islam beliau berpendapat bahwa Kaum muslim Indonesia menerima Pancasila

\footnotetext{
${ }^{23}$ Nurcholish Madjid, Islam Kemodernan.., h. 253

${ }^{24}$ Nurcholish Madjid, Dialog Keterbukaan... h. 186

${ }^{25}$ Nurcholish Madjid, Cita-Cita Politik Islam .. h. 67

26 lbid, h. 69
} 
dan UUD ada dua pertimbangan nilai-nilai yang dibenarkan ajaran agama Islam dan fungsinya sebagai simpul tali-temali kesepakatan antara berbagai golongan untuk mewujudkan kesatuan politik bersama. Begitu pula piagam Madinah (Konstitusi Madinah) yang merupakan rumusan prinsip-prinsip kesepakatan antar Muslim dan beberapa kelompok non-Islam untuk membangun masyarakat politik bersama, dan juga terdapat nilainilai yang dibenarkan oleh ajaran Islam. ${ }^{27}$

Perbandingan antara Pancasila dan Konstitusi Madinah atau Piagam Madinah adalah sama-sama menjadi Cammon Platform (titik temu) di antara kelompok-kelompok yang ada. Kontitusi Madinah waktu itu Nabi SAW mencoba untuk mempersatukan masyarakat Islam, Yahudi, dan lain-lainnya sehingga tercipta umat satu. Sebab itu mencari titik temu harus dilakukan secara kontinu. Dengan ini sebaiknya orang yang memandang agama sebagai ideologi itu harus berubah menjadi memandang sebagai sumber etik, dan anjuran kepada pemeluk agama Islam harus menyadari hak mereka sebagai pemeluk untuk mencari titik temu Pancasila dan agama, sehingga dapat melanjutkan cita-cita kemasyarakatan, politik, ekonomi dan lain-lain. Selain persamaan dalam dua hal tersebut; juga terdapat unsur implikasi ada hak dan kewajiban yang sama pada kelompok-kelompok bersangkutan dapat disejajarkan. Umat Islam berkewajiaban membela keutuhan bangsa dan mengoreksi pelaksanaannya dari sikap penyelewengan ${ }^{28}$ Sehingga tidak dibenarkan kalau orang Islam di Indonesia menganggap bahwa perlu akan mengganti dan tidak menerima Pancasila sebagai dasar negara; karena dari analisa perbandingan antara Piagam Madinah dan Pancasila maupun UUD 45 terdapat titik temu dan sesuai dengan cita-cita/misi ajaran agama Islam.

Ketiga,Tujuan Partai Politik Islam. Partai politik Islam sempat mempunyai tujuan mendirikan Negara Islam.Pada masa dulu dan

${ }^{27}$ Ibid, h. 56-58

${ }^{28}$ Nurcholish Madjid, Cita-Cita Politik Islam ..., h. 72

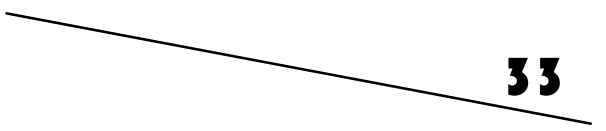


sekarang ada isu yang muncul seperti dulu; Negara Islam merupakan respon atas isu modernisasi yang persoalannya bukan memberi respon pada politik kontemporer, tapi lebih sebagai dialog internal Islam tentang arus pembentukan Negara Islam di dunia. Sejak tahun 1953 isu Negara Islam merupakan produk zaman modern,akibat pengaruh internasional, karena kalau bukan, mengapa Negara Islam dari dulu tidak pernah terjadi di Indonesia. ${ }^{29}$

Dalam menaggapi tentang ide untuk membentuk negara Islam bahwa Negara Islam merupakan bentuk eksklusifisme bukan inklusifisme, padahal sekarang Islam harus Inklusif. Aspirasi Negara Islam yang didukung oleh partai politik Islam dulu, tapi sekarang, di Indonesia hal itu sangat mustahil terjadi; karena yang menjadi tantangannya saat ini, agama diekspresikan dalam ungkapan yang lebih universalistik. Dengan kata lain, bahwa Islam dituntut untuk diekspresikan tidak secara khusus dan esoterik, dan harus diganti dengan simbol yang dapat difahami oleh semua orang. Kalau hanya memperhitungkan mayoritas saja itu mustahil terwujud; maka yang paling baik adalah nilai-nilai Islam yang bisa dirumuskan oleh umat Islam secara universal dan inklusivistik, seperti halnya masalah keadilan, persamaan, hak asasi, dan lain-lain, sehingga Negara (Islam) itu termasuk inklusif bukan eksklusif. ${ }^{30}$

Partai politik Islam pada tahun 1945-1950 berjuang untuk membuat Negara Islam, harus kita sadari bahwa menurut prosesproses kultural historis pada waktu itu, barangkali memang harus berbuat seperti itu. Tapi kita menilai hal itu tidak perlu diulang atau diteruskan karena keadaan sudah berubah.

Gagasan Negara Islam pernah muncul pada masa lalu dengan sangat kuat, karena suatu bentuk kecenderungan apologetis. ${ }^{31}$ Apologi itu ada karena ditujukan kepada ideologi Barat yang

\footnotetext{
${ }^{29}$ Nurcholish Madjid, Dialog Keterbukaan.......... h. 159

30 Ibid, h. 172-173

${ }^{31}$ Nurcholish Madjid, Islam Kemodernan..., h. 253-254
} 
bersifat menyeluruh dan meliputi setiap bidang kehidupan sehingga menimbulkan apresiasi yang bersifat ideologi kepada Islam dengan membawa cita-cita Negara Islam. Oleh karena itu, umat Islam mencoba menunjukkan bahwa Islam lebih unggul dibanding peradaban Barat, tetapi malah kalah dalam bidang ekonomi, politik, dan sosial. Perlu diketahui apologi seperti itu merupakan kompensasi rasa rendah diri dan pemikiran semacam itu punya efektivitas yang berumur pendek.

Adapun konsep Negara Islam merupakan suatu distorsi hubungan proporsional antara agama dan negara. Negara merupakan aspek kehidupan duniawi dengan dimensi rasional dan kolektif; sedangkan agama aspek kehidupan lain dengan dimensi spiritual dan pribadi. Dengan demikian agama dan negara bukan berarti dipisahkan - dan memang tidak dapat dipisahkan - tapi dibedakan dalam dimensi dan cara pendekatannya, ${ }^{32}$ Sehingga berdasarkan argumen tersebut tidak perlu kiranya kita membentuk Negara Islam.

Melihat sejarah partai politik Islam bahwa pada waktu dulu ada partai yang bersifat inklusif, seperti Partai Masyumi tahun 1950-an masih bersifat inklusif karena dalam wacana pergulatan tidak hanya dengan NU tapi meliputi PNI, PSI, Parkindo, Partai Katolik. Hal itu disebabkan Platform-nya Demokrasi Modern, berbeda dengan Masyumi pada tahun 1960-an yang masih terobsesi mendirikan Negara Islam dan terkungkung oleh retorikanya sendiri dalam memformalisasikan negara Islam di konstitusi. Dengan pengalaman seperti itu, semestinya ketika gagal memperjuangkan Negara Islam; mereka harus kembali pada tahun 1950-an yang telah sukses dengan tujuan Demokrasi dan telah ditujukkan oleh Kabinet Natsir yang termasuk Kabinet Demokrasi sejati. ${ }^{33}$ Memperjuangkan ide Negara Islam, sekarang tidak mungkin lagi; lebih baik perjuangkan nilai-nilai Islam. Tetapi kaum Muslim, melalui partai Islam mengemukakan gagasan

32 Ibid, h. 255-256

${ }^{33}$ Nurcholish Madjid, Dialog Keterbukaan........, h. 209-2I I

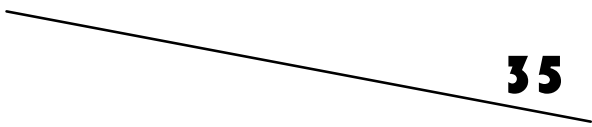


politik yang tidak semuanya sama dengan tuntutan dan kebutuhan negara ini, maka faktor ini dapat menimbulkan prasangka antara politik berorientasi Islam dan pemerintah yang berorientasi Nasional. Untuk meredakan prasangka itu sangat penting mendefinisikan Islam di Indonesia lebih inklusivistik sehingga simbol-simbol Islam harus bersifat terbuka dan mampu difahami semua muslim baik di luar maupun dalam pemerintahan. ${ }^{34}$ Sering pada masa lalu ada kesalah fahaman antara kedua belah pihak, akibat munculnya prasangka dan umat Islam mengalami peminggiran, termarjinalisasikan dalam percaturan politik, sehingga hal yang diperjuangkan dan dituntut kurang dapat difahami dan dimengerti oleh orang lain.

Pada zaman reformasi, Partai Politik Islam banyak berdiri, maka biarkanlah berkreasi dengan eksperimen-eksperimen dalam berdemokrasi karena demokrasi pada intinya adalah partisipasi politik secara terbuka dan setiap percobaan dalam partisipasi politik adalah hak setiap orang. ${ }^{35}$ Adapun keputusan akhir, kita percayakan kepada rakyat, dan upaya untuk mempersatukan satu partai dalam satu bendera itu adalah cara yang kuno dan harus ditinggalkan; karena tidak realistis lagi. ${ }^{36}$ Pada masa lalu terlihat atau muncul adanya Politik Aliran dalam pentas politik Nasional, menurut Nurcholish Madjid bahwa Politik Aliran pasti ada, sehingga bila ingin menghapuskan itu hanya omong kosong belaka. ${ }^{37}$ Sekarang Politik aliran tidak layak jual dan tidak relevan lagi pada saat ini, sehingga istilah santri dan abangan tidak relevan lagi; karena sekarang, para santri sudah menyebar kemana-mana, sehingga sepatutnya partai Islam bersikap lebih terbuka.

Sesuai dengan gerakan pembaharuan, pada saat ini dibutuhkan organisasi yang berimplikasikan non-tradisionalisme dan non-sektarianisme. Bagaimana peranan yang diambil partai

\footnotetext{
${ }^{34}$ Nurcholish Madjid, Islam Kemodernan.., h. 89

35 Hamid Basyaib dan Hamid Abidin (ed.), Mengapa Partai Islam Kalah ? Perjalanan Politik Islam dari Pra-Pemilu' 99 sampai Pemilihan Presiden (Jakarta:Alvabet, 1999), h. 294.

36 Ibid, h. 292

${ }^{37}$ Nurcholish Madjid, Dialog Keterbukaan.... h. 185-186
} 
Islam ? Peranan Partai Islam seharusnya menjadi oposisi loyal, ${ }^{38}$ agar orang Islam lebih efektif menjadi cheks and balance, kontrol untuk sambil berkuasa nantinya.

\section{Citra BaruTradisi Partai Politik Islam = Inklusifisme?}

Gerakan Politik Islam merupakan suatu manifestasi dari ajaran yang diajarkan oleh syariah-Nya, walaupun ketentuan yang bersifat menganjurkan di dalam Al-Qur'an tidak secara jelas tersurat di dalam ayat-ayat-Nya, namun hal ini dapat dipahami dari firman-firman-Nya yang tersurat dengan jelas sekali.

Politik Islam mempunyai corak Islami yang tentunya dapat dibedakan dengan politik yang berkembang di dunia Barat tentunya mempunyai ciri-ciri yang pokok bahwa ciri dari politik Islam adalah : Tidak ada paksaan serta kekerasan, tidak boleh menyesatkan, tidak boleh menjungkirbalikkan kebenaran, dan tidak menggunakan induksi-induksi psikotropika yang mengelabuhi masyarakat. Selain itu keterbukaan, kejujuran, rasa tanggungjawab serta berani mengemukakan yang batil itu batil dan yang baik itu baik.

Sementara itu Jurnalis asal Mesir, Fahmi Huwaydi mengatakan bahwa politik Islam itu identik dengan negara ( Islam), sehingga dia memberikan ciri-ciri politik Islam sama dengan ciri-ciri terintregasinya agama dengan kekuasaan negara yaitu :

a) Kekuasaan dipegang penuh oleh "umat"

Umat (rakyat) yang menentukan pilihan terhadap jalannya kekuasaan, dan persetujuannya merupakan syarat bagi kelangsungan orang-orang yang menjadi pilihan rakyat itu sendiri.

Dengan demikian bahwa rakyat merupakan pemilik kepemimpinan secara umum, dia berhak memilih dan yang mencabut jabatan Imam(pemimpin). Dengan kata lain umat adalah pemilik kekuasaan tersebut. namun demikian konsep yang

${ }^{38}$ Ibid, h. 292

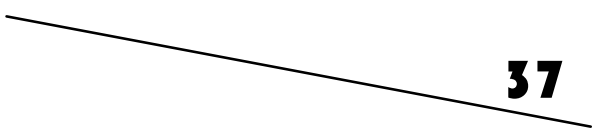


mengatakan kekuasaan di pegang penuh oleh umat. Hal ini perlu ada pembahasan yang dapat membedakan antara konsep Barat dengan konsep politik Islam. Dan di dalam Islam konsep tersebut sebenarnya sudah ada batasan yang nyata, yaitu asal tidak bertentangan dengan Al-Qur'an dan hadis Nabi.

b) Masyarakat juga ikut berperan amar ma`ruf dan bertanggungjawab

Penegakan agama, pemakmuran dunia serta pemeliharaan atas kemaslahatan umum merupakan tanggung jawab umat, bukan tanggung jawab penguasa saja. Seperti yang telah difirmankan oleh Allah dalam Al-Qur'an surat al-Maidah ayat 8 :

Ayat di atas secara langsung memerintahkan kepada kita untuk saling memenuhi kebutuhan dan membangun sinergi kekuatan bersama saling menguatkan barisan atau kepentingan yang satu dengan yang lainnya berasaskan keseimbangan, cheks and balances.

\section{c) Kebenaran adalah hak semua orang}

Ketentuan Islam tentang kebenaran berkeyakinan, adalah larangan bagi manusia untuk mempersempit seseorang hanya karena ia beraqidah lain dan berusaha untuk memaksakan aqidahnya kepada orang lain. Pemaksaan suatu aqidah merupakan suatu yang mustahil dan penghinaan terhadap orang lain karena aqidahnya merupakan suatu hal yang tidak dapat diterima sama sekali.

Jika ajaran Islam yang tercantum dalam syari'at Islam tidak memaksakan kepada setiap orang dalam kebebasannya, maka apakah logis hanya masalah sosial serta politik harus dipaksakan; sedangkan masalah di dalam aqidah saja Islam tidak memaksakan kepada manusia.

\section{d) Persamaan di antara semua orang}

Sesungguhnya nenek moyang manusia adalah sama yaitu Adam dan Hawa. Sedangkan di dalam Al-Qur'an itu sendiri menegaskan bahwa setiap manusia itu adalah sama, yang membedakan hanyalah taqwanya. Sedangkan yang berkenaan 
dengan urusan dunia di hadapan Allah adalah sama. Pangkat dan kedudukan adalah merupakan hiasan lahir bagi manusia saja. Jadi, tidak ada alasan yang kuat untuk membedakan antara manusia dengan manusia yang lain.

e) Kelompok yang berbeda juga memiliki legalitas

Sejak diputuskan kesatuan dasar kemanusiaan dan diterapkannya bagi setiap orang di dalam Al-Qur'an, maka setiap orang lain yang berbeda paham berhak mendapatkan perlindungan serta legalisasi sebagai manusia.

Lebih dari itu, Al-Qur'an telah mendeklarasikan, dan menyebutkan bahwa manusia di ciptakan berbeda baik suku maupun rasnya, hal ini memiliki hikmah tersendiri yaitu agar manusia saling mengenal dan berhubungan secara wajar. Berbeda itu merupakan dasar atau sunnatullah (hukum alami).

f) Kezaliman mutlak tidak dibolehkan dan usaha meluruskan adalah wajib

Dalam Islam kezaliman tidak hanya pada kemungkaran dan dosa besar saja, lebih dari itu juga masuk didalamnya adalah memperkosa hak-hak Allah dan menghancurkan nilai-nilai keadilan yang merupakan tujuan diutusnya Nabi kemuka bumi ini.

\section{g) Undang-undang di atas segalanya}

Legalitas kekuasaan di dalam negara Islam tegguh dan berlangsung dengan usaha mengomplementasikan sistem Undang-undang Islam secara keseluruhan tanpa membedakan hak-haknya yang mengatur tingkah laku seorang Muslim dalam kedudukannya sebagai anak bangsa dan hakim dengan nilai-nilai pokok dan tujuan-tujuannya yang mulia yang telah di sebutkan dalam Al-Qur'an serta hadis Nabi SAW. Demikianlah ciri-ciri gerakan politik Islam yang telah dituangkan oleh Fahmi Huwaydi. ${ }^{39}$

39 Fahmi Huwaydi, Demokrasi, Oposisi dan Masyarakat Madani,Isu-isu Besar Politik Islam, terj.M.Abdul Ghaffar E.M. (Bandung:Mizan, 1996), h. 160- 177.

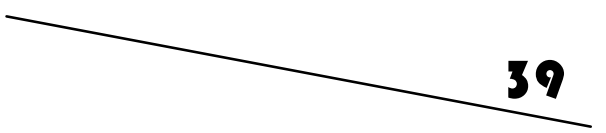


Dengan mengusung semangat keislaman yang universal, maka para pengurus baik di jajaran dewan syuro dan dewan tanfiziyah serta majelis pertimbangan partai/dewan pakar di masing-masing partai yang berasaskan idiologi Islam harus siap secara mentalitas dan semangat memahami nilai-nilai universalitas demokrasi dan demokratisasi yang elegan, adi luhung; para aktivis partai Islam harus mampu menerima dengan semangat keterbukaaan, inklusifitas partai Islam untuk diurus dan dikontrol secara kelembagaan oleh jajaran pengurus dari non-muslim dan tidak menutup diri bagi masukya kader-kader partai yang berkualitas dan memiliki track record diri yang handal dari kalangan yang tidak beragama Islam. Hal ini merupakan tolok ukur yang riel dalam alam demokrasi untuk mengembangkan citra baru tradisi dalam partai Islam yang mengedepankan politik rasionalitas dan tidak mengagungkan seorang tokoh besar dan idiologi-kharismatik dari sang tokoh.Dalam partai Islam harus dapat melepaskan bayang-bayang tokoh besar, restu dari tokoh kharismatik untuk menciptakan tradisi baru berupa format politik Islam yang berkarakter nahniyah (politik altruistik), politik kebersamaan, kekitaan, dan keumatan; dan membuang jauh paradigma politik yang hegemonik dan didominasi oleh bayangbayang tokoh besar dan pengaruh kharisma tokoh yang bersifat ananiyah (politik egosentris), satu kelompok, dan eksklusif. Modal inilah yang akan mengembalikan citra partai Islam yang demokratis dan inklusif dengan mengedepankan jamaah dan keumatan/kerakyataan dan orang-orang partai tidak mengusung romantisme sejarah dalam perjuangan politik partai islam yang modern dan strategis.

\section{Penutup}

Dalam era ketebukaan informasi dan era demokratisasi dalam kehidupan perpolitikan Indonesia, senantiasa terjadi pergulatan politik antara nilai idealitas dan tuntutan pragmatisme politik, hendaklah para penggiat politik, aktifis politik pro rakyat dan 
khususnya partai politik harus dapat memahami karakteristik masyarakat Indonesia yang sangat peduli politik yang bercitra kerakyatan, sensitif terhadap kebutuhan dasar rakyat serta aspiratif terhadap suara rakyat.

Dalam hal ini, parpol yang berbasis Islam dan kebangsaan harus merivisi ulang doktrin perjuangan politiknya agar lebih toleran dan terbuka berupa nilai-nilai politik nahniyah, yakni perjuangan politik yang bersifat kerakyatan, politik altruistik, bukan lagi politik idiologis yang bersifat kaku, doktriner yang sudah lapuk dimakan zaman dan menjauhi politik ananiyah yang bersifat egosektoral dan tidak responsif terhadap kepentingan ummat yang pluralistik. Era politik alokatif harus menjadi basis kinerja politik baru dalam membangun peradaban politik yang adi luhung di Indonesia.

\section{Daftar Pustaka}

Al Jabiri, Muhammad Abed, Post Tradisionalisme Islam, terj. Ahmad Baso Jogyakarta: LkiS.

Anwar, M.Syafi'I, Pemikiran dan Aksi Islam Indonesia Sebuah Kajian

Politik Tentang Cendekiawan Muslim Orde Baru, Jakarta: Paramadina, 1995.

Basyaib, Hamid, (ed.), Mengapa Partai Islam Kalah? Perjalanan Politik Islam dari Pra-Pemilu'99 sampai Pemilihan Presiden, Jakarta: Alvabet, 1999.

Benda, Hari J., Bulan Sabit dan Matahari Terbit, Jakarta: Dunia Pustaka Jaya, 1990.

Chaidar, Ali, Pemili 1999 Pertarungan Idiologis Partai-partai Islam Versus Partai Sekuler, Jakarta: Darul Falah, 2001.

Cipto, Bambang, Partai Politik, Jogyakarta: Pustaka Pelajar,1996. Huwaydi, Fahmi, Demokrasi, Oposisi dan Masyarakat Madani, Isu-isu Besar Politik Islam, terj.M.Abdul Ghaffar E.M., Bandung:Mizan, 1996.

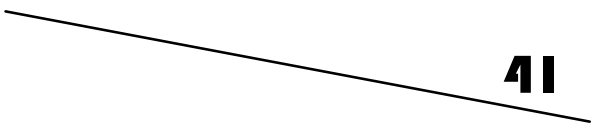


Karim, M.Rusli, Perjalanan Partai Politik di Indonesia: Sebuah Potret Pasang Surut, Jakarta: R.Grafindo Persada, 1993.

Kuntowijoyo, Identitas Politik Umat Islam, Bandung:Mizan, 1997.

Madjid, Nurcholish, Cita-Cita Politik Islam Era Reformasi, Jakarta: Paramadina, 1999.

-------, Islam Kemodernan dan Keindonesiaan, Bandung: Mizan,1999.

Noer, Deliar, Partai Islam di Pentas Nasional 1945-1956, Jakarta: Pustaka Utama Grafiti, 1987.

Poerwadarminta, W.J.S., Kamus Umum Bahasa Indonesia, Jakarta: Balai Pustaka, 1993.

Thaba, Abdul Aziz, Islam dan Negara Dalam Politik Orde Baru, Jakarta: Gema Insani Press, 1996. 